Hydrol. Earth Syst. Sci. Discuss., doi:10.5194/hess-2016-471, 2016

\title{
The role of forest maturity on catchment hydrologic stability
}

Oscar Belmar ${ }^{1}$, José Barquín ${ }^{1}$, Jose Manuel Álvarez-Martínez ${ }^{1}$, Francisco J. Peñas ${ }^{1}$, Manuel Del Jesus $^{1}$

${ }^{1}$ Environmental Hydraulics Institute, Universidad de Cantabria - Avda. Isabel Torres, 15, Parque Científico y Tecnológico

5 de Cantabria, 39011, Santander, Spain

Correspondence to: Oscar Belmar (oscar.belmar@unican.es)

\begin{abstract}
Land cover and soil properties largely determine how climatic and hydrological regimes interact and produce hydrological stress in aquatic ecosystems. This study aims to clarify the influence of forests, as well as other majoritarian land cover types, on hydrological regime through an experimental design without the main limitations associated with 10 traditional paired-watershed studies. With this aim, we use more catchments and an additional forest descriptor: forest maturity. We focus on flood and drought regimes, as they constitute the extremes of hydrological variability. Specific objectives were to isolate the relative contribution of precipitation and land cover composition to such flow extremes and to contrast the effectiveness of forests (surface and maturity) and other land cover types to predict them. The study was developed in a heterogeneous region located in the Cantabrian Mountains (NW Spain) with different vegetation types and a long history of human disturbance and land use change that allowed a robust experimental design. Regression and partial correlation analyses were developed using hydrological and meteorological data combined through hydrological modelling using IHACRES. Land cover characteristics showed ability to predict both flood regimes and low flows, although low flows were explained mainly by precipitation regimes. Forests showed a stabilization effect on flow regime (lower floods and greater base flows), but the effect was more evident with forest maturity than with surface. Other land cover types showed

20 different effects. Evaluating the role of land cover on hydrological stability requires the use of comprehensive information involving different descriptors and their temporal changes, not only the current surface occupied by each land cover type.
\end{abstract}

Keywords. Cantabrian Mountains, Native Forests, Maturity, Flow regime, Land use, River disturbance, IHACRES

\section{Introduction}

Flood and drought events represent the extreme demonstration of hydrologic variability, which constitutes a primary driver of stream biological communities and ecosystem functioning (Resh et al. 1988; Lake 2000). Such events may cause greater impacts on river ecosystems than changes in average conditions (Woodward et al. 2016), and their frequency, intensity and duration are expected to increase due to Climate Change (IPCC 2012). In addition, land use changes may also affect flood and drought phenology (e.g. Scott and Lesch 1997), and therefore their consequences on ecosystems.

Forest area has increased in Europe over the last decades (Spiecker et al. 2012). Socioeconomic adjustments, such as those 30 linked to the EU Common Agricultural Policy (CAP), have led to a dramatic rural exodus and subsequent abandonment of 
Hydrol. Earth Syst. Sci. Discuss., doi:10.5194/hess-2016-471, 2016

Manuscript under review for journal Hydrol. Earth Syst. Sci.

Published: 4 October 2016

(c) Author(s) 2016. CC-BY 3.0 License.

agricultural land, a cessation of coppicing and a reduction in grazing in natural communities (e.g.: Benayas et al. 2007). Today, forests cover nearly $40 \%$ of the European surface (European Commission 2015). Their trees have greater water requirements than other vegetation types, as they intercept more precipitation and present greater transpiration rates (e.g. Bosch and Hewlett 1982). Thus, their expected effect on river flows would be a general reduction when forests spread, grow 5 and mature (Johnson 1998).

The development of paired-watershed experimental designs has aimed to clarify forest influence on the water cycle (Hewlett 1971, 1982; Cosandey 1995). These studies are generally based on selecting two similar and geographically close watersheds, subjected to the same climatic regime, and assuming that different hydrologic responses will be driven by differences in forest extent. Their results generally indicate that the effect of forest expansion is a decrease in water yield

10 (both flood volumes and peaks). Nevertheless, additional watershed-scale research is necessary to advance our understanding of forest impact on hydrology. Particularly, studies focused on large basins (several tens of km2), additional descriptors of forest characteristics (besides area) and a larger number of observed watersheds (instead of only two) (Andréassian 2004). More complete studies that clarify the relationship between forests and hydrological processes may allow improving the design of strategies to face the effects of Climate Change on catchment hydrology. In this context, forest maturity may be an

15 important factor to determine forest-river flow relationships, as the long process of native forests formation involves many steps that increase water retention. Tree roots grow into fissures and aid in the breakdown of bedrock, penetrating compacted soil layers and allowing soil aeration and water infiltration. In addition, a vegetative ground cover modifies the temperature and moisture conditions below (Fisher and Stone 1969; Fisher and Eastburn 1974). Given the interaction of these processes with the hydrological cycle, the use of maturity as a descriptor of forest characteristics in experimental designs may improve 20 our understanding of forests' influence on river ecosystems at a watershed scale.

The aim of this study is to improve the understanding of how forests and other predominant land cover patches influence flood and drought patterns at a watershed scale through an experimental field design without the limitations of pairedwatershed studies. We use several large catchments in the Cantabrian Mountains (NW Spain) with a gradient of forest cover due to human management since the 15th century. We defined forest cover not only through forest surface but also using forest maturity. Our specific objectives are: (i) to isolate the relative contribution of precipitation regimes and land cover to hydrological extreme events and (ii) to compare the effectiveness of forest, as well as other predominant land cover types, surface and maturity to predict such extremes. We expect mature forests to smooth hydrological extremes caused by precipitation regimes through water interception and retention, in opposition to other land cover types. Thus, forest maturity is expected to be negatively associated with floods and positively related to base flows, inducing hydrologic stability. Such

30 outcome would be relevant for environmental management in order to face the effects of Climate Change in river ecosystems at catchment scale. 
Hydrol. Earth Syst. Sci. Discuss., doi:10.5194/hess-2016-471, 2016

Manuscript under review for journal Hydrol. Earth Syst. Sci.

Published: 4 October 2016

\section{Material and methods}

\subsection{Study area}

This study has been developed in the Cantabrian Mountains, which extend for more than $300 \mathrm{~km}$ across northern Spain, nearly parallel to the Cantabrian Sea. They constitute a distinct physiographic province of the larger Alpine System

5 physiographic division. Glaciers and fluvial erosion are the two main processes that have shaped their relief, composed mainly of sedimentary materials such as limestone and conglomerates. These mountains present an Atlantic climate with annual precipitation and temperature around $1160 \mathrm{~mm}$ and $9.5^{\circ} \mathrm{C}$, respectively. Areas located at lower latitudes show subMediterranean characteristics, with higher temperatures and summer droughts (Ninyerola et al 2007). This environmental heterogeneity shelters a mix of tree species with beeches (Fagus sylvatica), birches (Betula ssp.) and different species of oaks

10 (Quercus petraea, Q. robur, Q. pyrenaica and Q. rotundifolia) in a transition from the Atlantic to the sub-Mediterranean areas. Shrub vegetation spans a similar gradient, varying from semi-arid communities mixed with annual grasslands and crops in the southeast to shrubs and young forests in the north and west, with alpine vegetation and bare rock at higher elevations and slopes.

A set of 16 catchments, later reduced to 10 due to data quality issues (see Meteorological and hydrological data; Fig. 1,

15 Table 1), was selected to represent a land cover gradient within a similar climatic region. Such gradient characterizes the legacy of human management and land use practices for the last 400 years. After the foundation of the Real Fábrica de Artillería de la Cavada (in English, the Royal Artillery Factory in La Cavada) in 1616, the native forests in the Eastern extreme were intensively exploited for more than 200 years in order to obtain wood for naval construction. Since then, this area has been kept deforested for stockbreeding through the combined use of fire and cattle grazing. Consequently, the

20 Eastern part of the study area is dominated by a mixture of shrubs with a dominance of dry heathland communities and extensive pastureland. Only some isolated patches of forest remain in steep hillslopes. On the contrary, the western catchments have not suffered massive deforestation and still present quite well developed mature forests. The presence of brown bear (Ursus arctos) and Cantabrian Capercaillie (Tetrao urogallus cantabricus) in these catchments, unlike the eastern extreme (González et al. 2016; Blanco-Fontao et al. 2012), evidences a better state of conservation.

\section{$25 \quad 2.2$ Land cover characteristics}

Land cover information was obtained from a supervised classification approach of remote sensing imagery. A suitable Landsat TM image of the study area taken in 2010, with a minimum cloud cover and a relatively high sun elevation angle, was downloaded from the United States Geological Survey (USGS). The image was radiometrically and atmospherically corrected using the algorithms available in GRASS (2013). A complementary digital elevation model (DEM) was obtained

30 from LiDAR data (CNIG 2014) and resampled to 30 meters to match the spatial resolution of the image. A per-pixel classification approach was applied using a Maximum Likelihood algorithm (ML) over a combination of spectral information and topographic layers derived from the 30-m DEM. The ML algorithm assigned pixels to the land cover class 
Hydrol. Earth Syst. Sci. Discuss., doi:10.5194/hess-2016-471, 2016

Manuscript under review for journal Hydrol. Earth Syst. Sci.

Published: 4 October 2016

(c) Author(s) 2016. CC-BY 3.0 License.

with maximum membership probability, although they may have an almost equal probability of membership to another class (Lewis et al. 2000). Simultaneously, a fuzzy k-means classification allowed yielding membership probabilities for each land cover type at the pixel level (see more details in Álvarez-Martínez et al. 2010). The relative surface occupied by each land cover class in each catchment was obtained using the result of the ML algorithm. However, forest maturity was estimated

5 using the membership probabilities obtained through the fuzzy classification, calculating the average per-pixel forest probability in each of the selected catchments. Pixels with a higher forest probability represent dense forest patches that can be interpreted like developed, mature forests. Higher forest probability can be interpreted like greater forest maturity.

\subsection{Meteorological and hydrological data}

Meteorological records were acquired from the Spain02 database (version 4), developed by the Agencia Estatal de 10 Meteorología (AEMET, the State Meteorological Agency) and the Universidad de Cantabria (UC, University of Cantabria). Such database includes gridded datasets interpolated with rainfall and temperature data from over 2500 stations in Spain at different resolutions for the period 1971-2007 (Herrera et al. 2012; 2016). Meteorological series (rainfall and temperature) were obtained by averaging those cells belonging to the grid within each catchment. The resulting rainfall and temperature series were represented using box-plots in order to verify that the catchments in the study area presented reasonably similar

15 climatic regimes.

Flows recorded by the Red Oficial de Estaciones de Aforo (ROEA, the Official Network of Gauging Stations) were obtained from the Anuario de Aforos database available online at the Centre for Studies and Experimentation on Public Works (CEDEX, 2016). Only the gauging stations located at the outlet of each sub-basin were retained. After testing flow records in order to detect deficiencies (see details in Peñas et al. 2014), 6 out of the initial 16 stations (and their corresponding sub-

20 basins) were discarded from the study: one in the Duero Basin (2034; Fig. 1) and the five in the Ebro Basin (9092, 9178, 9202, 9203 and 9254; Fig. 1). The flow series of the remaining 10 stations were divided by the mean to allow inter-basin comparison (Poff et al 2006).

\subsection{Hydrological analyses}

Three flow indices were chosen, based on those used by Olden and Poff (2003): (i) the maximum 3-day mean annual flow

25 (M3DMF); (ii) the mean number of high flow events per year using an upper threshold of 9 times the median flow over all years (FRE9) and (iii) the Base Flow Index (BFI, the seven-day minimum flow divided by mean annual daily flow averaged across all years). The latter was used to characterise low-flow conditions, whereas the two others were used to characterise flood regimes (magnitude and frequency). The period selected for computation was 1995-2010, in order to ensure 15 years of records (Kennard et al. 2010) and match the timing of the image taken by the USGS. These indices were also calculated 30 using contemporary precipitation series (P-M3DMF, P-FRE9 and P-BFI).

Water interception and retention caused by ground vegetation and soil development were estimated determining the proportions of slow and quick flows through a physical model that uses precipitation, temperature and flow data: IHACRES. 
Hydrol. Earth Syst. Sci. Discuss., doi:10.5194/hess-2016-471, 2016

Manuscript under review for journal Hydrol. Earth Syst. Sci.

Published: 4 October 2016

(c) Author(s) 2016. CC-BY 3.0 License.

A detailed description is provided in Jakeman and Hornberger (1993). It is composed of a non-linear loss module that converts precipitation to effective precipitation and a linear routing model that converts effective precipitation to streamflow. The non-linear module comprises a storage coefficient (c), a time constant for the rate of drying (tw) of the catchment at a fixed temperature $\left(20^{\circ} \mathrm{C}\right)$ and a factor (f) that modulates for changes in temperature. A configuration of two parallel storages

5 in the linear routing module was implemented. By doing so, the proportional volume of the quick flow (vq) to slow flow (vs) storage response for each of the 10 selected catchments was obtained through calibration using the period for which our data were best (2000-2007).

\subsection{Analysis of the effect of climate and land use on hydrological regime}

The effects of precipitation and land cover on the selected hydrological indices were isolated through partial correlation 10 analysis. The three hydrological indices (M3DMF, FRE9 and BFI) were predicted through Ordinary Least Square (OLS) regression modelling using the three precipitation indices (P-M3DMF, P-FRE9 and P-BFI). Then, by means of new OLS regression modelling, we explored whether land cover characteristics predicted the hydrological variance not explained by precipitation indices (i.e. the residuals of the first model run). In order to contrast the effectiveness of different land cover characteristics to predict hydrological extremes and water interception and retention, land cover characteristics were used to

15 predict the hydrological indices and the proportional volumes of the quick (vq) and slow (vs) flows through a new OLS regression modelling.

Dependent variables were transformed to reduce heteroscedasticity (King et al. 2005), using decimal logarithms for flow indices and the arcsine of the squared root for the volumes of quick and slow flows, as they were proportions (McDonald 2014). All analyses were developed using the R software (version 3.1.3; R Core Team 2015) through the base package 20 "stats".

\section{Results}

The catchments in the western extreme showed larger areas covered by forests as well as higher values of forest maturity, whereas those in the eastern extreme presented the lowest values of both parameters. Shrub surface showed the opposite pattern. Pastureland did not show clear differences across the study area (Table 1). The ten studied catchments displayed reasonably similar climatic regimes, with only a very subtle gradient in climatic characteristics from West to East (Fig. 2). Only the Base Flow Index showed correlation with precipitation regimes (Table 2). On the contrary, the hydrological indices associated with the magnitude and frequency of floods (M3DMF and FRE9) showed a very low correlation with precipitation. Land cover characteristics, particularly shrub surface and forest maturity, showed a significant relationship with M3DMF and FRE9 after removing the effect of precipitation. In all partial correlations, forest maturity showed higher correlation scores with hydrological indices than forest surface. 
Hydrol. Earth Syst. Sci. Discuss., doi:10.5194/hess-2016-471, 2016

Manuscript under review for journal Hydrol. Earth Syst. Sci.

Published: 4 October 2016

(c) Author(s) 2016. CC-BY 3.0 License.

Forest maturity and shrubs surface showed the highest ability for hydrological extremes prediction (Fig. 3). Forest maturity showed a negative relationship with the magnitude and frequency of floods and positive with the base flow, while shrub surface showed opposite trends. Forest maturity and shrubs surface also showed the highest ability for quick/slow flow prediction, as the R2 values and p-values of the OLS modelling evidenced (Fig. 4). Slow flows were positively correlated

5 with forests maturity and negatively with shrubs. Therefore, like in the partial correlations, forest maturity performed better than forest surface in hydrological prediction.

\section{Discussion}

This study shows that land cover may be more relevant than precipitation to determine the spatial variability of flow extremes in similar, close catchments and points out forest maturity as one key factor to explain hydrological variability, more effective than forest surface. We reckon that the complex land cover mosaic and land cover dynamics of the selected region in the Cantabrian Mountains (NW Spain) has largely contributed to produce statistically significant modelling results even with a relatively low number of cases. We consider that such results have implications for water management in areas with similar climate, land cover types and land uses (i.e. in temperate Atlantic catchments).

\subsection{Precipitation and land cover contribution to flow extremes}

15 Precipitation and land cover have different relative contributions to floods and droughts, as partial correlations showed. The spatial variation of floods is determined mainly by land cover characteristics, which implies a huge effect of the land cover mosaic on torrentiality at a catchment scale. Droughts are explained mainly by precipitation regimes. This means that land cover characteristics are unable to overcome the impact of critical reductions in water incomes. However, a moderate influence of land cover on droughts has also been observed, as land cover characteristics showed ability to predict also low

20 flows (not only floods).

This study indicates that mature forests confer hydrological stability to river flows. Catchments with higher forest maturity presented less intense and frequent floods and greater base flows. Forest maturity also predicted the spatial variability of slow and quick flows better in the selected catchments. Croke et al. (2004) observed the same pattern between forests and the proportional volume of quick and slow flow storage using surface. However, they obtained their results in a relatively small

25 sub-basin through simulation by combining a generic crop model (CATCHCROP; Perez et al. 2002) with IHACRES. The use of several (and larger) catchments (as Andréassian 2004 suggested) and estimates both of forest surface and maturity in this study based on real data provides more reliable results. Given the higher performance obtained, the use of forest maturity determined by forest probability obtained through fuzzy-logic approaches (see Álvarez-Martínez et al. 2010) may provide an income for hydrologic modelling capable of producing better results. This is especially relevant for water 30 research due to the widely spread use of vegetation surface in such modelling (e.g. Soil and Water Assessment Tool, SWAT; Arnold et al. 1998). 
Hydrol. Earth Syst. Sci. Discuss., doi:10.5194/hess-2016-471, 2016

Manuscript under review for journal Hydrol. Earth Syst. Sci.

Published: 4 October 2016

(c) Author(s) 2016. CC-BY 3.0 License.

\subsection{Implications for forest management}

The role that mature forests may play conferring hydrological stability at a catchment scale is unlikely to be accomplished by reforestations. Frequently, reforestation efforts are based on a comparatively small number of fast-growing exotic species. These species have particular environmental preferences and, not surprisingly, many do not always grow as well as expected

5 (e.g. Lamb et al. 2005). Reforestations are then likely to lack a developed ground vegetation cover and a mature soil (at least, during the first decades). They will be less effective in intercepting and retaining precipitation, and therefore, in providing base flows. Instead, their water consumption may contribute to water scarcity and aridification (Jackson et al. 2005; Brown et al. 2005; Sun et al. 2006). Consequently, whereas native forest expansion and maturation could constitute a powerful strategy to counteract the effects of Climate Change in the mid- to long-term through flow regime stabilization, the

10 deterioration of native forests due to human land use management in a context of Climate Change will exacerbate its effects and constitute a drawback impossible to undo in the short term.

\subsection{The importance of recent past in land cover mosaic}

The different performance in hydrologic prediction showed by forest surface and maturity may be related to landscape dynamics. Besides the exploitation that the forests in the study area experienced since the 15th century, the Cantabrian

15 Mountains have showed a major decline in livestock grazing pressure for the last 40 years (Morán Ordóñez et al. 2011, Álvarez-Martínez et al. 2013). This has resulted in a displacement of shrubs and pastureland by native forests in many different areas (Poyatos et al. 2003; Álvarez-Martínez et al. 2014). In our case, more than 10\% of pixels classified as forest in 2010 were pasture or shrub in 1984 (unpublished data). This involves that new forest surface comprises a mixture of pixels with different degree of development, and with different hydrological effect at a catchment scale. New forest pixels

20 would present then reduced ground vegetation, organic matter decomposition and soil development (Binkley and Fisher 2012) than if they were occupied by mature forests. We believe that this might be the main reason why forest surface has a poorer ability to explain the spatial variability of hydrological indices, while forest maturity performed much better.

Similarly, the different performance showed by other land cover types not associated with forests also indicates an influence of land cover dynamics on hydrological response. Pastureland was not a good predictor, whereas shrub surface was highly related to hydrological instability. The lack of relationship between pastureland and hydrological indices could be caused by the low representation of pastures in the study area in comparison with dominant land cover types (i.e. forests and shrubs). On the contrary, the better performance of shrubs may be related to land use management, which makes shrub lands a dominant land cover through the extensive and recurrent use of fire (Pausas and Fernández-Muñoz 2012; Regos et al. 2015). Commonly, the shrubs in the study area present a pattern of degraded vegetation and poor soil structure associated with 30 recurrently burnt areas (Díaz-Delgado et al. 2002; Gimeno-García et al. 2007). In this context, the development of additional land cover descriptors, such as maturity for forests, remains necessary to explore the effects of land cover mosaics on hydrological response at a catchment scale. 
Hydrol. Earth Syst. Sci. Discuss., doi:10.5194/hess-2016-471, 2016

Manuscript under review for journal Hydrol. Earth Syst. Sci.

Published: 4 October 2016

(c) Author(s) 2016. CC-BY 3.0 License.

Finally, further research on the long-term impacts of land cover on hydrologic regimes at a catchment scale may provide key guidelines for a sustainable land use management. First, through the development of more complex designs based on land cover dynamics. For example, using data from different years during the last decades. By doing so, the changes in climate, flows and land cover could be quantified and compared in order to determine the relative contribution of landscape dynamics

5 to hydrological change during the selected period (with a complete understanding of the performance of land cover characteristics through the observation of their changes during those years and some on ground measurements when possible). Unfortunately, such analyses were not possible in our study area due to data availability and quality issues. Second, with hydrologic models based on additional land cover descriptors to extension (such as maturity, for forests). That would allow mimicking land cover-hydrology interactions more accurately. Finally, we consider that understanding the physical mechanisms that may explain the interactions herein observed is mandatory. The influence of tree physiological conditions (e.g. basal area, live biomass or leaf area) deserves special attention, considering the impressive water holding capacity of $\mathrm{O}$ horizons (for example, a $5 \mathrm{~cm}$ thick $\mathrm{O}$ horizon in a sub-alpine forest might have a mass of about $5 \mathrm{~kg} \mathrm{~m}-2$ and could retain about 10 litres of water; Golding and Stanton 1972). By doing so, we will be able to better assess the contribution of native forests and native forest soils to flow regimes through base flows at a catchment scale, as well as the contribution of other land cover types to quick flows.

\section{Author contributions}

OB performed research, analysed data and wrote the paper. JB conceived the study, performed research and contributed to analyses and writing. JMAM performed research and contributed to analyses and writing. FJP contributed to analyses and writing. MDJ performed research and contributed to writing.

\section{Competing interests}

The authors declare that they have no conflict of interest.

\section{Acknowledgements and Funding Information}

We wish to thank the Ministry for Economy and Competitiveness for its support to the projects "Land use legacy effects on river processes: implications for integrated catchment management (RIVERLANDS; BIA2012-33572)" and "Effects of

25 Hydrological Alteration on River Functioning and Service Provisioning: Implications for Integrated Catchment Management (HYDRA; BIA2015-71197)”. We also thank AEMET and UC for the data provided (Spain02 v4 EURO-CORDEX dataset, http://www.meteo.unican.es/datasets/spain02) and Joaquin Bedia for his advice on climatic data processing. Mario ÁlvarezCabria, Ana Silió, Edurne Estévez, Alexia González-Ferreras, Tamara Rodríguez-Castillo, María Lezcano, Ignacio Pérez- 
Hydrol. Earth Syst. Sci. Discuss., doi:10.5194/hess-2016-471, 2016

Manuscript under review for journal Hydrol. Earth Syst. Sci.

Published: 4 October 2016

(c) Author(s) 2016. CC-BY 3.0 License.

Silos and Mireya Cayon revised an early draft of the manuscript. Finally, we also wish to thank the Ministry for Economy and Competitiveness for its financial support to José Barquín and Oscar Belmar through the Ramón y Cajal (RYC-201108313) and Juan de la Cierva (FPDI-2013-16141) programs, respectively.

\section{References}

5 Alvarez-Martinez, J., Gomez-Villar, A., \& Lasanta, T. (2013). The Use of Goats Grazing to Restore Pastures Invaded by Shrubs and Avoid Desertification: A Preliminary Case Study in the Spanish Cantabrian Mountains. Land Degradation \& Development, 27, 3-13

Alvarez-Martinez, J.M., Stoorvogel, J.J., Suarez-Seoane, S., \& Calabuig, E.D. (2010). Uncertainty analysis as a tool for refining land dynamics modelling on changing landscapes: a case study in a Spanish Natural Park. Landscape Ecology, 25,

$10 \quad 1385-1404$

Alvarez-Martinez, J.M., Suarez-Seoane, S., Stoorvogel, J.J., \& Calabuig, E.D. (2014). Influence of land use and climate on recent forest expansion: a case study in the Eurosiberian-Mediterranean limit of north-west Spain. Journal of Ecology, 102, 905-919

Andreassian, V. (2004). Waters and forests: from historical controversy to scientific debate. Journal of Hydrology, 291, 1-27

15 Arnold, J.G., Srinivasan, R., Muttiah, R.S., \& Williams, J.R. (1998). Large area hydrologic modeling and assessment - Part 1: Model development. Journal of the American Water Resources Association, 34, 73-89

Benayas, J.M., Martins, A., Nicolau, J.M., \& Schluz, J.J. (2007). Abandonment of Agricultural Land: An Overview of Drivers and Consequences. CAB Reviews: Perspectives in Agriculture, Veterinary Science, Nutrition and Natural Resources, 2, 1-14

20 Binkley, D., \& Fisher, R.F. (2012). Ecology and management of forest soils. John Wiley \& Sons

Blanco-Fontao, B., Obeso, J.R., Banuelos, M.J., \& Quevedo, M. (2012). Habitat partitioning and molting site fidelity in Tetrao urogallus cantabricus revealed through stable isotopes analysis. Journal of Ornithology, 153, 555-562

Bosch, J.M., \& Hewlett, J.D. (1982). A Review of Catchment Experiments to Determine the Effect of Vegetation Changes on Water Yield and Evapo-Transpiration. Journal of Hydrology, 55, 3-23

25 Brown, A.E., Zhang, L., McMahon, T.A., Western, A.W., \& Vertessy, R.A. (2005). A review of paired catchment studies for determining changes in water yield resulting from alterations in vegetation. Journal of Hydrology, 310, 28-61

CEDEX (2016). Anuario de aforos 2012-2013. In http://ceh-flumen64.cedex.es/anuarioaforos/default.asp

CNIG (2014). Download centre. Online virtual shop. In http://www.cnig.es. G.d.E. Centro Nacional de Información Geográfica. Instituto Geográfico Nacional, Gobierno de España

30 Comission, E. (2015). FOREST website. In http://forest.jrc.ec.europa.eu/

Cosandey, C. (1995). La forêt réduit-elle l'écoulement annuel? Annales de Géographie, 581-582, 7-25 
Hydrol. Earth Syst. Sci. Discuss., doi:10.5194/hess-2016-471, 2016

Manuscript under review for journal Hydrol. Earth Syst. Sci.

Published: 4 October 2016

(C) Author(s) 2016. CC-BY 3.0 License.
Hydrology and

Earth System

Sciences

Discussions

(c) (i)

Croke, B.F.W., Merritt, W.S., \& Jakeman, A.J. (2004). A dynamic model for predicting hydrologic response to land cover changes in gauged and ungauged catchments. Journal of Hydrology, 291, 115-131

Diaz-Delgado, R., Lloret, F., Pons, X., \& Terradas, J. (2002). Satellite evidence of decreasing resilience in Mediterranean plant communities after recurrent wildfires. Ecology, 83, 2293-2303

5 Fisher, R.F., \& Eastburn, R.P. (1974). Afforestation Alters Prairie Soil Nitrogen Status. Soil Science Society of America Journal, 38, 366-368

Fisher, R.F., \& Stone, E.L. (1969). Increased Availability of Nitrogen and Phosphorus in Root Zone of Conifers. Soil Science Society of America Proceedings, 33, 955-961

Gimeno-Garcia, E., Andreu, V., \& Rubio, J.L. (2007). Influence of vegetation recovery on water erosion at short and medium-term after experimental fires in a Mediterranean shrubland. Catena, 69, 150-160

Golding, D.L., \& Stanton, C.R. (1972). Water storage in the forest floor of subalpine forests of Alberta. Canadian Journal of Forest Research, 2, 1-6

Gonzalez, E.G., Blanco, J.C., Ballesteros, F., Alcaraz, L., Palomero, G., \& Doadrio, I. (2016). Genetic and demographic recovery of an isolated population of brown bear Ursus arctos L., 1758. Peerj, 4:e1928; DOI 10.7717/peerj.1928

GRASS (2013). GRASS 6.4.3. Geographic Resources Analysis Support System

Herrera, S., Fernandez, J., \& Gutierrez, J.M. (2016). Update of the Spain02 gridded observational dataset for EUROCORDEX evaluation: assessing the effect of the interpolation methodology. International Journal of Climatology, 36, 900908

Herrera, S., Gutierrez, J.M., Ancell, R., Pons, M.R., Frias, M.D., \& Fernandez, J. (2012). Development and analysis of a 50-

20 year high-resolution daily gridded precipitation dataset over Spain (Spain02). International Journal of Climatology, 32, 7485

Hewlett, J.D. (1982). Principles of Forest Hydrology. Athens: The University of Georgia Press

IPCC (2012). Managing the Risks of Extreme Events and Disasters to Advance Climate Change Adaptation. A Special Report of Working Groups I and II of the Intergovernmental Panel on Climate Change. In C.B. Field, V. Barros, T.F.

25 Stocker, D. Qin, D.J. Dokken, K.L. Ebi, M.D. Mastrandrea, K.J. Mach, G.-K. Plattner, S.K. Allen, M. Tignor, P.M. Midgley (Ed.) (p. 582). Cambridge (UK) and New York (NY, USA): Cambridge University Press

Jackson, R.B., Jobbagy, E.G., Avissar, R., Roy, S.B., Barrett, D.J., Cook, C.W., Farley, K.A., le Maitre, D.C., McCarl, B.A., \& Murray, B.C. (2005). Trading water for carbon with biological sequestration. Science, 310, 1944-1947

Jakeman, A.J., \& Hornberger, G.M. (1993). How Much Complexity Is Warranted in a Rainfall-Runoff Model. Water

30 Resources Research, 29, 2637-2649

Johnson, R. (1998). The forest cycle and low river flows. A review of UK and international studies. Forest Ecology and Management, 109, 1-7

Kennard, M.J., Mackay, S.J., Pusey, B.J., Olden, J.D., \& Marsh, N. (2010). Quantifying Uncertainty in Estimation of Hydrologic Metrics for Ecohydrological Studies. River Research and Applications, 26, 137-156 
Hydrol. Earth Syst. Sci. Discuss., doi:10.5194/hess-2016-471, 2016

Manuscript under review for journal Hydrol. Earth Syst. Sci.

Published: 4 October 2016

(c) Author(s) 2016. CC-BY 3.0 License.

King, R.S., Baker, M.E., Whigham, D.F., Weller, D.E., Jordan, T.E., Kazyak, P.F., \& Hurd, M.K. (2005). Spatial considerations for linking watershed land cover to ecological indicators in streams. Ecological Applications, 15, 137-153

Lake, P.S. (2000). Disturbance, patchiness, and diversity in streams. Journal of the North American Benthological Society, 19, 573-592

5 Lamb, D. (2005). Helping forests take cover. In V. Poopathy, S. Appanah, \& P.B. Durst (Eds.), On forest protection, increasing forest cover and future approaches to reforesting degraded tropical landscapes in Asia and the Pacific. Bangkok (Thailand): Food and Agriculture Organization of the United Nations Regional Centre for Asia and the Pacific

Lewis, H.G., Brown, M., \& Tatnall, A.R.L. (2000). Incorporating uncertainty in land cover classification from remote sensing imagery. Remote Sensing for Land Surface Characterisation, 26, 1123-1126

10 McDonald, J.H. (2014). Handbook of Biological Statistics. (3rd ed.). Baltimore (MD, USA): Sparky House Publishing Moran-Ordonez, A., Suarez-Seoane, S., Calvo, L., \& de Luis, E. (2011). Using predictive models as a spatially explicit support tool for managing cultural landscapes. Applied Geography, 31, 839-848

Ninyerola, M., Pons, X., \& Roure, J.M. (2007). Monthly precipitation mapping of the Iberian Peninsula using spatial interpolation tools implemented in a Geographic Information System. Theoretical and Applied Climatology, 89, 195-209

15 Olden, J.D., \& Poff, N.L. (2003). Redundancy and the choice of hydrologic indices for characterizing streamflow regimes. River Research and Applications, 19, 101-121

Pausas, J.G., \& Fernandez-Munoz, S. (2012). Fire regime changes in the Western Mediterranean Basin: from fuel-limited to drought-driven fire regime. Climatic Change, 110, 215-226

Peñas, F.J., Barquin, J., Snelder, T.H., Booker, D.J., \& Alvarez, C. (2014). The influence of methodological procedures on

20 hydrological classification performance. Hydrology and Earth System Sciences, 18, 3393-3409

Perez, P., Ardlie, N., Kuneepong, P., Dietrich, C., \& Merritt, W.S. (2002). CATCHCROP: modeling crop yield and water demand for integrated catchment assessment in Northern Thailand. Environmental Modelling \& Software, 17, $251-259$

Poff, N.L., Olden, J.D., Pepin, D.M., \& Bledsoe, B.P. (2006). Placing global stream flow variability in geographic and geomorphic contexts. River Research and Applications, 22, 149-166

25 Poyatos, R., Latron, J., \& Llorens, P. (2003). Land use and land cover change after agricultural abandonment - The case of a Mediterranean Mountain Area (Catalan Pre-Pyrenees). Mountain Research and Development, 23, 362-368

Regos, A., Ninyerola, M., More, G., \& Pons, X. (2015). Linking land cover dynamics with driving forces in mountain landscape of the Northwestern Iberian Peninsula. International Journal of Applied Earth Observation and Geoinformation, $38,1-14$

30 Resh, V.H., Brown, A.V., Covich, A.P., Gurtz, M.E., Li, H.W., Minshall, G.W., Reice, S.R., Sheldon, A.L., Wallace, J.B., \& Wissmar, R.C. (1988). The Role of Disturbance in Stream Ecology. Journal of the North American Benthological Society, 7, 433-455

Scott, D.F., \& Lesch, W. (1997). Streamflow responses to afforestation with Eucalyptus grandis and Pinus patula and to felling in the Mokobulaan experimental catchments, South Africa. Journal of Hydrology, 199, 360-377 
Hydrol. Earth Syst. Sci. Discuss., doi:10.5194/hess-2016-471, 2016

Manuscript under review for journal Hydrol. Earth Syst. Sci.

Published: 4 October 2016

(c) Author(s) 2016. CC-BY 3.0 License.

(c) (1)

Spiecker, H., Mielikäinen, K., Köhl, M., \& Skovsgaard, J.P. (2012). Growth trends in European forests: studies from 12 countries. Springer Science \& Business Media

Sun, G., Zhou, G.Y., Zhang, Z.Q., Wei, X.H., McNulty, S.G., \& Vose, J.M. (2006). Potential water yield reduction due to forestation across China. Journal of Hydrology, 328, 548-558

5 Team, R.C. (2015). R: A language and environment for statistical computing. In: R Foundation for Statistical Computing, Vienna (Austria)

Woodward, G., Bonada, N., Brown, L.E., Death, R.G., Durance, I., Gray, C., Hladyz, S., Ledger, M.E., Milner, A.M.,

Ormerod, S.J., Thompson, R.M., \& Pawar, S. (2016). The effects of climatic fluctuations and extreme events on running water ecosystems. Philosophical Transactions of the Royal Society B-Biological Sciences, 371: 20150274 
Hydrol. Earth Syst. Sci. Discuss., doi:10.5194/hess-2016-471, 2016

Manuscript under review for journal Hydrol. Earth Syst. Sci.

Published: 4 October 2016

(c) Author(s) 2016. CC-BY 3.0 License.

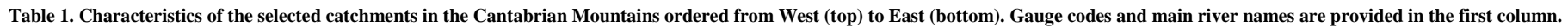

\begin{tabular}{|c|c|c|c|c|c|c|c|c|c|}
\hline \multirow[b]{2}{*}{ Code (Name) } & \multicolumn{5}{|c|}{ Geologic and hydrologic characteristics } & \multicolumn{4}{|c|}{ Land cover characteristics (\%) } \\
\hline & $\begin{array}{l}\text { Area } \\
\left(\mathrm{km}^{2}\right)\end{array}$ & $\begin{array}{c}\text { Altitude } \\
(\mathrm{m})\end{array}$ & $\begin{array}{c}\text { Slope } \\
(\%)\end{array}$ & $\begin{array}{c}\text { Mean runoff } \\
\left(\mathrm{hm}^{3}\right)\end{array}$ & $\begin{array}{c}\text { Mean flow } \\
\left(\mathrm{m}^{3} / \mathrm{s}\right)\end{array}$ & $\begin{array}{c}\text { Forest } \\
\text { maturity }\end{array}$ & Forest surface & Shrub surface & Pasture surface \\
\hline 1296 (Ponga) & 34 & 1277 & 29 & 55 & 2 & 82 & 62 & 33 & 3 \\
\hline 1295 (Sella) & 480 & 1005 & 29 & 627 & 18 & 75 & 41 & 42 & 6 \\
\hline 1274 (Cares) & 266 & 1454 & 31 & 245 & 8 & 72 & 15 & 32 & 9 \\
\hline 2035 (Besandino) & 70 & 1498 & 19 & 33 & 1 & 52 & 7 & 45 & 17 \\
\hline 1265 (Deva - O.) & 296 & 1185 & 26 & 141 & 4 & 77 & 39 & 35 & 12 \\
\hline 1268 (Deva - P.) & 648 & 1029 & 27 & 415 & 15 & 75 & 38 & 38 & 11 \\
\hline 1264 (Bullón) & 156 & 972 & 25 & 63 & 2 & 78 & 56 & 31 & 10 \\
\hline 1215 (Pas) & 358 & 599 & 19 & 270 & 9 & 55 & 33 & 57 & 7 \\
\hline 1207 (Miera) & 161 & 563 & 21 & 147 & 5 & 48 & 22 & 64 & 9 \\
\hline 1196 (Asón) & 492 & 558 & 20 & 649 & 22 & 62 & 32 & 47 & 14 \\
\hline
\end{tabular}

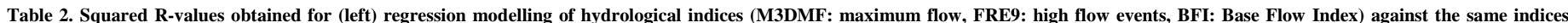

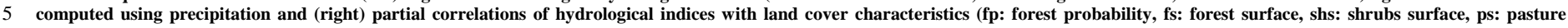
surface). Values are expressed in percentage. Significance levels: ${ }^{\prime}{ }^{\prime} \leq 0,1 ;{ }^{\prime *}, \leq 0,05 ;{ }^{\prime} * *, \leq 0,01$.

\begin{tabular}{|c|c|c|c|c|c|c|c|}
\hline \multirow[b]{2}{*}{ Hydrological index } & \multicolumn{3}{|c|}{$\begin{array}{l}\text { Precipitation indices } \\
\text { (regression model) }\end{array}$} & \multicolumn{4}{|c|}{$\begin{array}{l}\text { Land cover characteristics } \\
\text { (partial correlation) }\end{array}$} \\
\hline & P-M3DMF & P-FRE9 & P-BFI & $\mathrm{fp}$ & fs & shs & ps \\
\hline M3DMF & 07 & - & - & $* 47$ & 10 & $* * 69$ & 03 \\
\hline FRE9 & - & 05 & - & $\cdot 36$ & 01 & $* * 65$ & 04 \\
\hline BFI & - & - & * 53 & 24 & 10 & 10 & 11 \\
\hline
\end{tabular}


Hydrol. Earth Syst. Sci. Discuss., doi:10.5194/hess-2016-471, 2016

Manuscript under review for journal Hydrol. Earth Syst. Sci.

Published: 4 October 2016

(c) Author(s) 2016. CC-BY 3.0 License.

(c) (1)
Hydrology and

Earth System

Sciences

Discussions
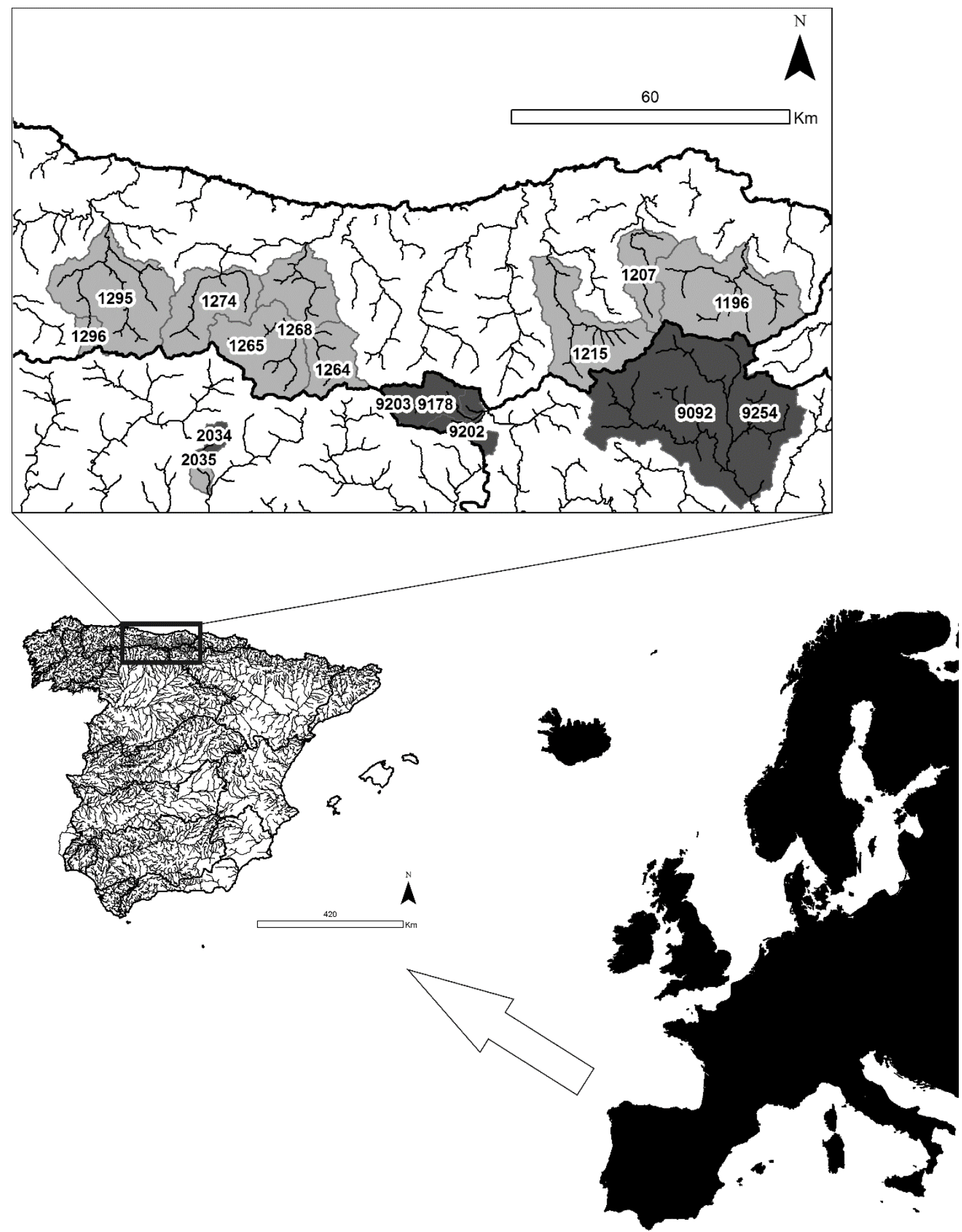

Figure 1. Catchments with hydrological records in the study area of the Cantabrian Mountains. The darkest catchments were discarded due to the poor quality of their data. 
Hydrol. Earth Syst. Sci. Discuss., doi:10.5194/hess-2016-471, 2016

Manuscript under review for journal Hydrol. Earth Syst. Sci.

Published: 4 October 2016

(c) Author(s) 2016. CC-BY 3.0 License.
Hydrology and

Earth System

Sciences

Discussions
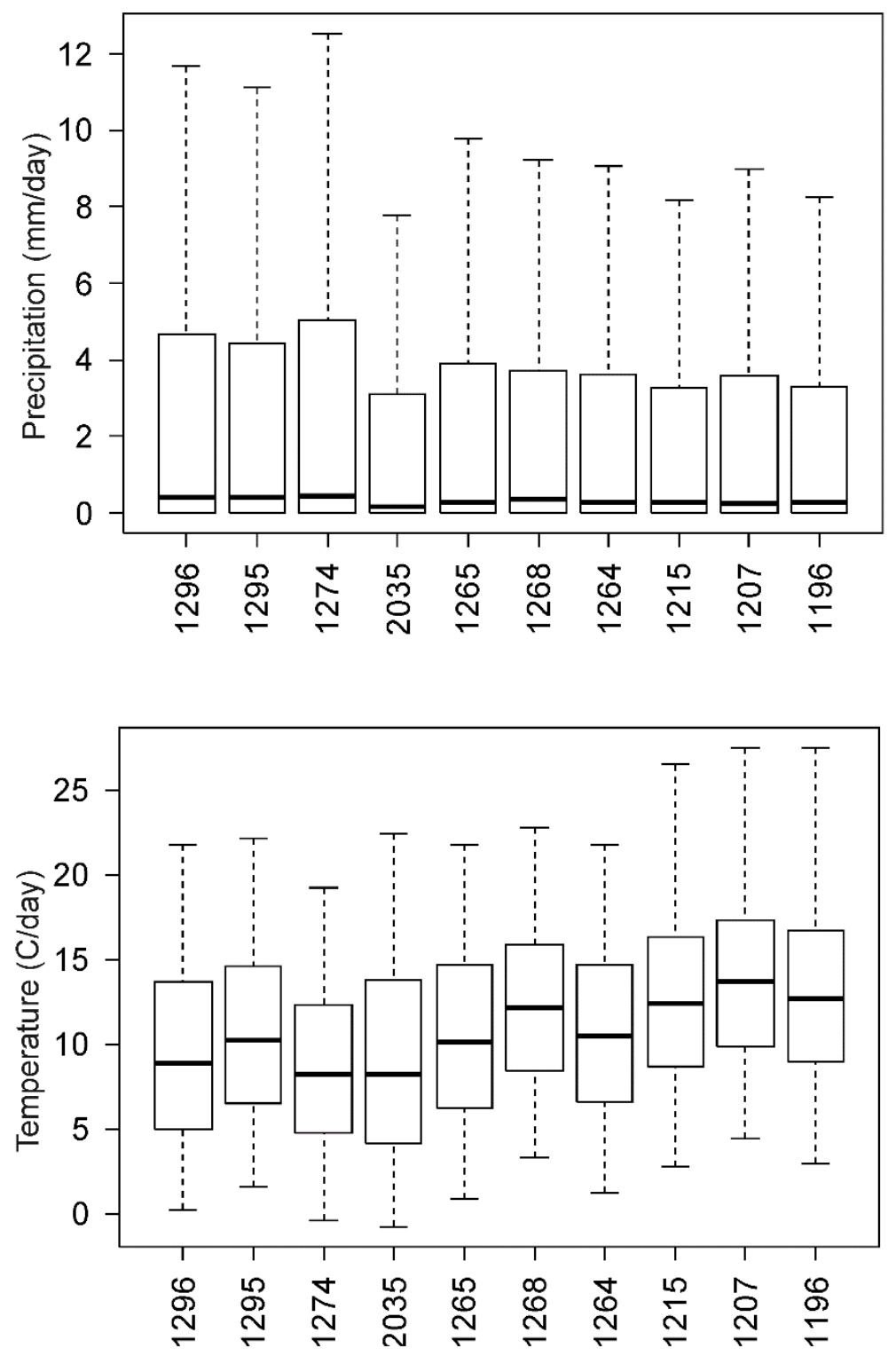

Figure 2. Daily precipitation and temperature variability for the period 1995-2010 in the 10 catchments of the Cantabrian Mountains, ordered from West (left) to East (right). Boxplots show quartiles. Whiskers show maxima and minima (outliers excluded). 
Hydrol. Earth Syst. Sci. Discuss., doi:10.5194/hess-2016-471, 2016

Manuscript under review for journal Hydrol. Earth Syst. Sci.

Published: 4 October 2016

(c) Author(s) 2016. CC-BY 3.0 License.
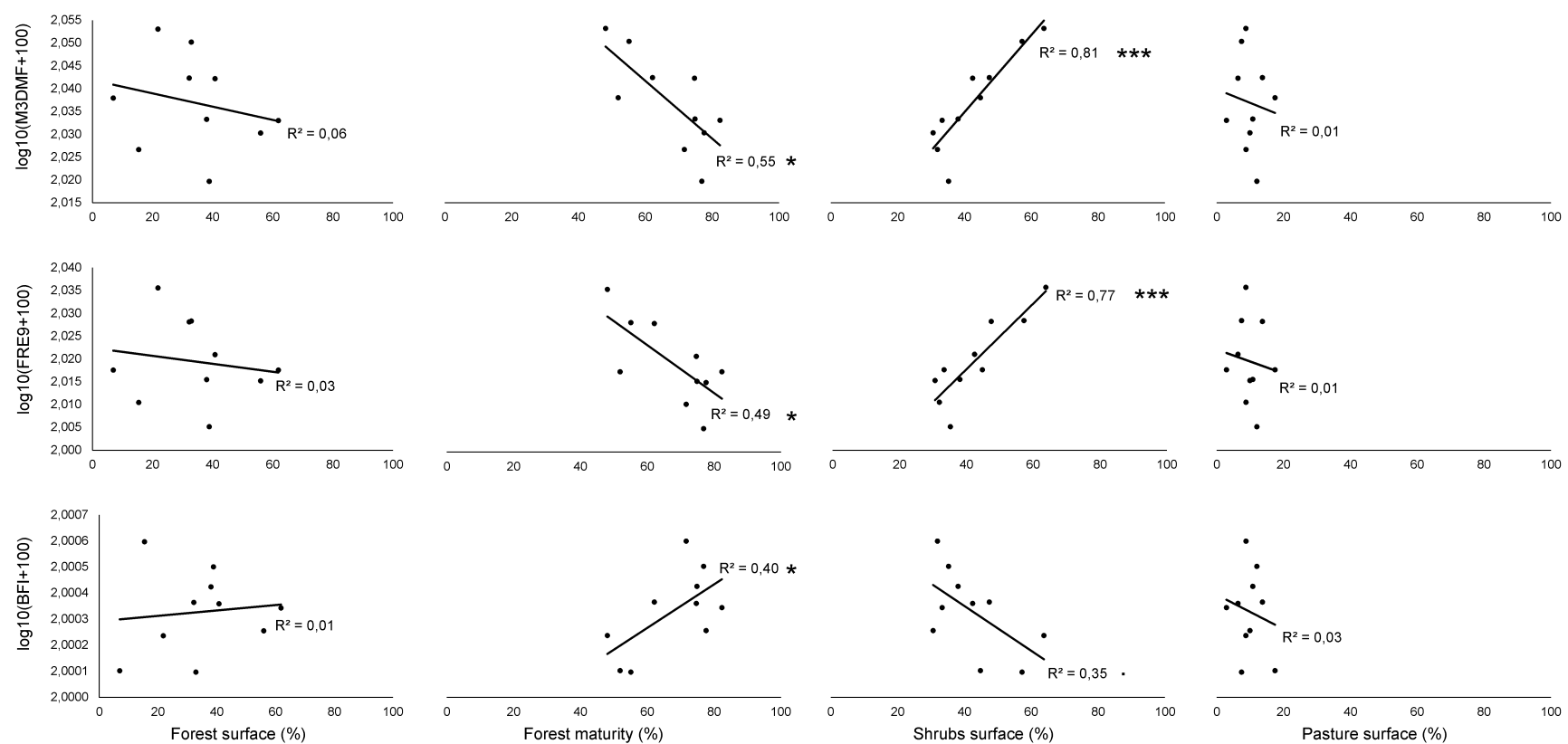

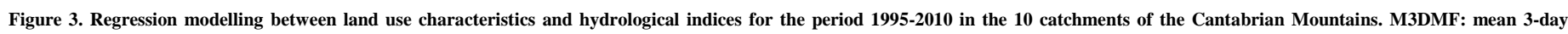

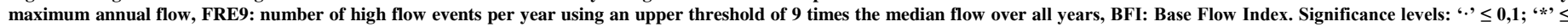
0,$05 ;{ }^{*} * *, \leq 0,01 ;{ }^{\prime *} * * ' \leq 0,001$ 
Hydrol. Earth Syst. Sci. Discuss., doi:10.5194/hess-2016-471, 2016

Manuscript under review for journal Hydrol. Earth Syst. Sci.

Published: 4 October 2016

(c) Author(s) 2016. CC-BY 3.0 License.

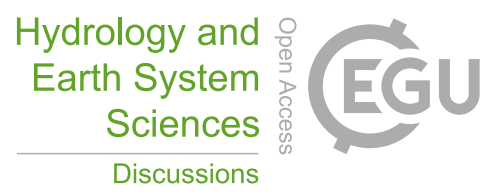

(c) (1)
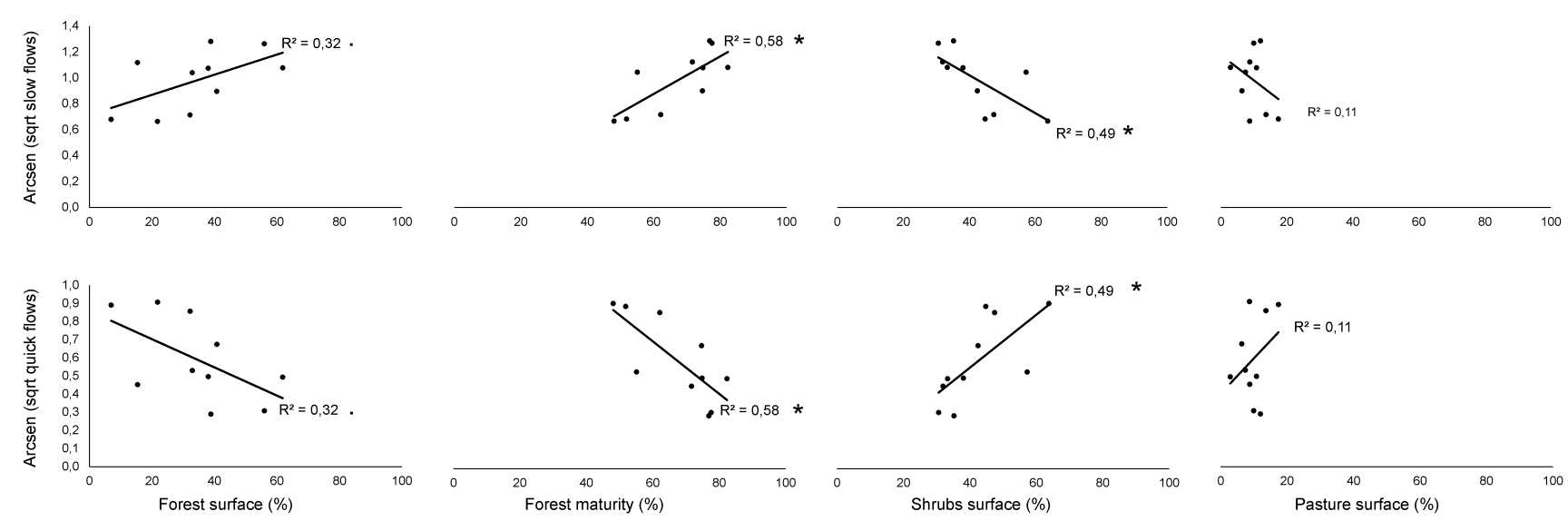

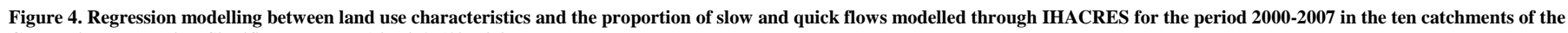
Cantabrian Mountains. Significance levels: ' $’ \leq 0,1 ;{ }^{\prime}{ }^{\prime}, \leq 0,05$. 